\title{
Protocolo de valoracion de la efectividad de productos protectores de pizarras para cubiertas
}

\section{Protocol for assessing the effectiveness of protective coatings for roofing slate}

\author{
$\underline{\text { V. Cárdenes }}^{(*)}$, J. García-Guinea(**), C. Monterroso(***) y R. de la Horra(****)
}

Recepción/Received: 15-V-07

Aceptación/Accepted: 17-IX-07

Publicado online/Online publishing: 22-XI-07

\section{RESUMEN}

España es líder mundial en producción de pizarras de techar; la producción supera las 600.000 toneladas de pizarra de gran calidad, suponiendo más de 300 millones de euros. La aplicación de la pizarra con productos protectores permite comercializar placas más oxidables reduciendo escombreras y problemas ambientales. El presente protocolo sirve para evaluar estos nuevos productos protectores que empiezan a utilizarse en el sector pizarrero. Se propone una combinación de tres ensayos tecnológicos junto con un cuestionario visual para otorgar índices de calidad. Cada ensayo está orientado para clarificar una propiedad importante en el uso de la pizarra de techar: (i) Ciclo térmico para determinar el grado de oxidación de los sulfuros de hierro; (ii) Exposición al gas $\mathrm{SO}_{2}$ para conocer su comportamiento en ambientes urbanos ácidos; (iii) Exposición a la niebla salina y rayos UV para evaluar la eficacia de la capa protectora frente a la corrosión salina y la radiación solar.

Palabras clave: protocolo, pizarras, productos protectores, oxidación, pirita.

\begin{abstract}
SUMMARY
Spain is a world-wide leader in roofing slate production, quarriying more than 600,000 tons of slate of great quality and generating around 300 euros million in sales each year. However, an enormous quantity of slate plates is considered as a low quality product or discarded every year as waste. The application of protective products on roofing slate tiles helps to commercialise slate with higher oxidation rates, reducing wastes and environmental problems. The present protocol serves to evaluate the new protective products that are now used by slate producers. A combination of three technological tests is proposed here, along with a visual questionnaire to grant quality indices. Each test is oriented to clarify critical properties for the future use of the roofing slate, as follows: (i) Thermal cycles were used to determine the oxidation rate of iron sulphides; (ii) Slate behaviour in acid urban atmospheres was interpreted by exposition of slate tiles to $\mathrm{SO}_{2}$ gas; (iii) Effectiveness of the protective layer under saline corrosion and solar radiation was obtained by exposition to saline fog and UV-irradiation.
\end{abstract}

Keywords: protocol, slate, protective products, oxidation, pyrite.

\footnotetext{
(*) Fundación Centro Tecnológico de la Pizarra (Orense, España).

(**) Museo Nacional Ciencias Naturales. CSIC (Madrid, España).

(***) Universidad Santiago de Compostela. (Santiago de Compostela, España).

(****) Instituto de Geología Económica UCM-CSIC. (Madrid, España). 


\section{INTRODUCCIÓN}

La producción minero-industrial española de pizarra supera actualmente las 600.000 toneladas suponiendo aproximadamente unos 300 millones de euros (1) (Figura 1). Los efectos de la actividad biológica aparecen desde las primeras etapas de exposición de la roca a la intemperie (2-4), pudiendo ser desde simples cambios estéticos, derivados de la presencia de pigmentos biológicos (5), hasta complejos cambios físico-químicos (4).

\section{INTRODUCTION}

The production of Spanish roofing slate goes beyond the 600,000 tons generating about 300 million Euros per year (1) (Figure 1). The features of weathering can become visible from the first stages of the outdoors slate placement (2-4). They can be related to simple aesthetic changes linked with biological pigments (5), but also to complex physical-chemical changes related to biological activity (4).

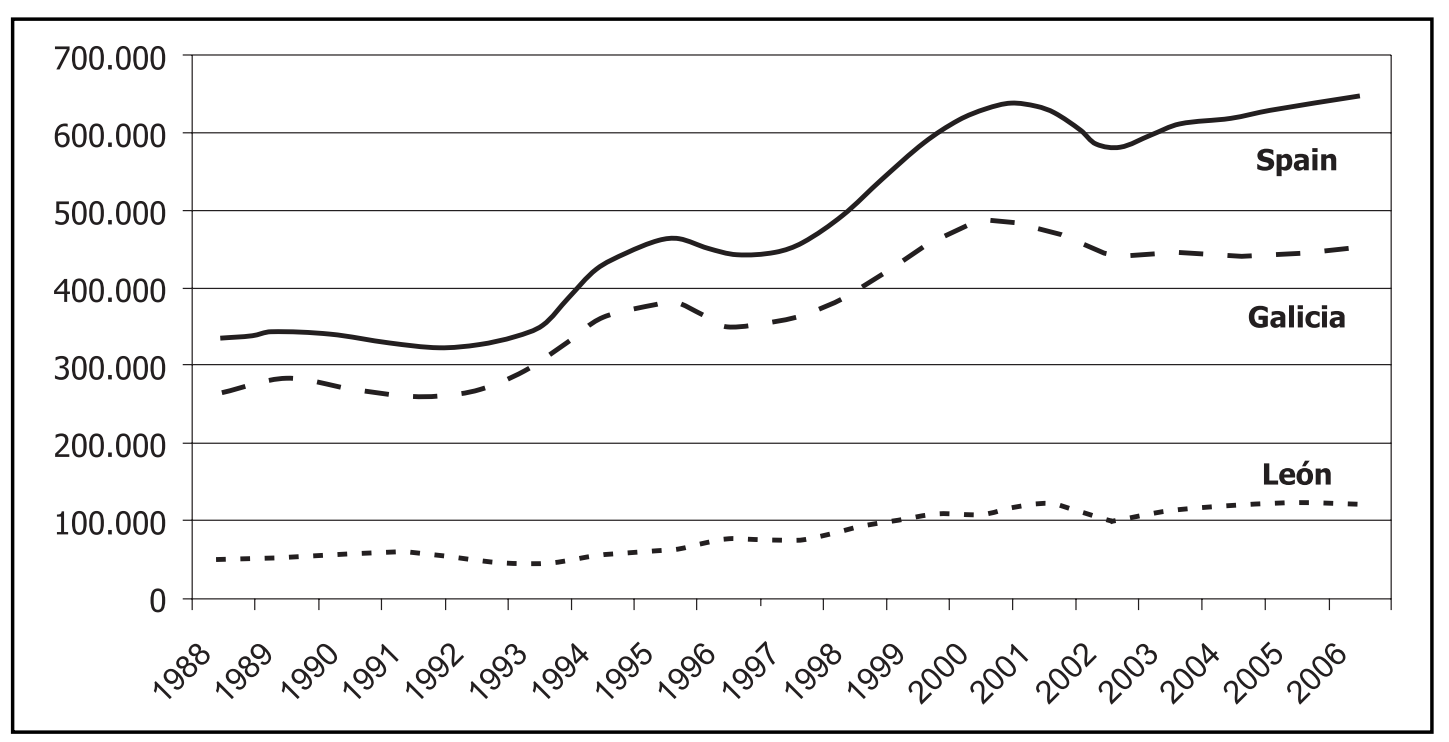

Figura 1. Producción de pizarra de techar en España en los últimos 18 años expresada en toneladas métricas.

Figure 1. Roofing slate production in Spain during the last 18 years expressed in metric tons.

La colonización biológica depende de las condiciones ambientales (luz, temperatura, humedad) y de las características intrínsecas de la roca (rugosidad superficial, porosidad, permeabilidad, composición mineralógica) porque condicionan el suministro potencial de agua y nutrientes, determinando la biorreceptividad de las rocas o su susceptibilidad para ser colonizadas (6). Los primeros colonizadores de las rocas son algas y cianobacterias, quienes, junto con junto con musgos y plantas vasculares, son los organismos más agresivos por su naturaleza fotosintética. También se pueden desarrollar fácilmente bacterias quicio-autótrofas, que obtienen su energía a través de la oxidación de compuestos inorgánicos (amonio, nitrito, azufre, sulfuro) liberando ácidos minerales fuertes (ácido nítrico, ácido sulfúrico) que aceleran las reacciones de acidólisis. Tras la acumulación de compuestos orgánicos, pueden aparecer bacterias quimioheterótrofas y hongos. Estos organismos liberan ácidos orgánicos complejantes, con un elevado poder corrosivo (biocorrosión), o extraen Fe y Mn de los minerales por oxidación (4). Entre los primeros colonizadores también son frecuentes los líquenes; son asociaciones simbióticas
Biological colonization depends on the environmental conditions (light, temperature, humidity) and intrinsic characteristics of the rock (superficial topography, permeability, mineralogical). These factors modify the potential water supply and nutrients, determining the rock bio-receptivity or its susceptibility to be colonized (6). The first colonizers of rocks are seaweed and cyanbacteria, which together with dark-brown and vascular plants are the most aggressive organisms by their photosynthetic activity. Additional growing of chemoautotrophs bacteria is also possible because they obtain energy throughout the inorganic compound oxidation (ammonium, nitrite, sulphur, sulphide) releasing acid strong mineral acids (nitric acid, sulphuric acid), which accelerate the acid-lysis reactions. After the organic matter accumulates, chemoheterotrophs bacteria and fungi can also appear. These organisms release organic complexant acids with a high potential corrosion (bio-corrosion) or extract Fe and Mn from mineral phases by oxidation mechanisms (4). Among the first colonizer types, lichens are also frequent. Lichens are symbiotic associations of green algae or cyano-bacteria and fungus. In this 
entre algas o cianobacterias y hongos en las que el hongo utiliza los nutrientes producidos por el alga y ésta obtiene minerales lixiviados por los ácidos orgánicos excretados por el hongo y protección frente a desecación.

La alteración es un proceso complejo, específico del tipo de roca y del lugar de exposición lo que dificulta la generalización de tratamientos protectores. La oxidación de sulfuros de hierro es uno de los principales procesos de alteración en pizarras que sólo produce cambios en el color natural de la piedra como efecto negativo de tipo estético y muy raramente llega a dañar o agujerear la placa. Sin embargo, los principales países importadores de pizarra, Francia, Alemania y Bélgica califican como producto de baja calidad a la pizarra con estas alteraciones reduciendo su mercado potencial. Actualmente se están desarrollando productos químicos específicos para proteger a la placa de pizarra de la intemperie, pero los correspondientes ensayos de laboratorio necesarios para evaluar dichos productos no están bien desarrollados todavía, porque este tipo de tratamientos específicos sólo han sido aplicados a la pizarra muy recientemente. La pizarra es muy buen material aislante y tiene muy baja permeabilidad, características que dificultan la impregnación del producto protector. En este artículo se analizan detalladamente las principales causas y circunstancias de la alteración en pizarras y propone un protocolo para evaluar la efectividad de los nuevos tratamientos de protección en pizarras para cubiertas.

\section{MÉTODOS DE PROTECCIÓN}

Los estudios sobre inhibición de la alteración de los sulfuros de hierro habitualmente se realizan para el drenaje ácido en escombreras de minas de carbón (7-9). La solución más común a este problema propone añadir piedra caliza a la escombrera, lo que aumenta el pH e inhibe la alteración. Otra propuesta sugiere recubrir la superficie de la pirita (10-12), o pirrotina (13), mediante lixiviación del material con una solución de silicato sódico $\left(\mathrm{Na}_{2} \mathrm{SiO}_{3}\right)$ o fosfato potásico $\left(\mathrm{KH}_{2} \mathrm{PO}_{4}\right)$. El oleato de sodio también crea una capa hidrofóbica que protege la superficie del sulfuro de hierro evitando el contacto con el oxígeno del agua (14). También se ha estudiado un fosfolípido (23:2 Diyne PC, comercializado por Avanti Polar Lipids) como agente recubridor que crea una capa de marcado carácter polar sobre la superficie del sulfuro de hierro (15-16), así como siloxanos y otros compuestos protectores (17). Otros caminos explorados son el recubrimiento catiónico de la pirita utilizando electrólisis (18) o el uso de resinas sintéticas para proteger ejemplares de piritas expuestas en museos frente a la acción de los rayos UV (19). Estas propuestas consiguen reducir la tasa de oxidación de los sulfuros de hierro, pero ninguna de ellas ha fructificado symbiosis, the fungus use the food produced by the alga from sunlight. The alga or cyan-bacteria might fix atmospheric nitrogen for metabolic use, or to obtain lixiviated minerals by organic acids produced by the fungi, and it provide protection in opposition to desiccation.

Natural weathering is a complex process linked with the properties of the rock and the specific settlement. For this reason, the use of standard protective procedures is very complicated. Nowadays, different specific chemical agents are being developed to protect the slate plate from weathering. However, as these specific treatments have been applied to roofing slate only very recently, the necessary corresponding tests of laboratory to evaluate these products are still not established. Slate is a very good insulating material and it has very low permeability, but those characteristics make difficult the coating impregnation of the protective products. Here we analyse the main causes and circumstances involved in slate weathering proposing a new protocol to evaluate the effectiveness of the new treatments protecting roofing slates.

\section{PROTECTION METHODOLOGY}

Studies on the inhibition of the iron sulphides alteration have been applied to prevent the acid drainage from coal mining waste (7-9). The most common solution suggests adding limestone to the acid waste tailings, since increasing the $\mathrm{pH}$ the weathering of iron sulphides slow down. Other interesting suggestion is to cover the pyrite surface (10-12), or pyrrothite outer (13), by lixiviation with a solution of sodium silicate $\left(\mathrm{Na}_{2} \mathrm{SiO}_{3}\right)$ or potassium phosphate $\left(\mathrm{KH}_{2} \mathrm{PO}_{4}\right)$. Sodium oleate also creates a hydrophobic layer, which protects the surface of the iron sulphide, preventing further contact with the environmental oxygen (14). Additional studies has been focused on the phospholipid 23:2 Diyne PC, commercialised by Avanti Polar Lipids as a covering product which creates a polar layer onto the iron sulphate surface (15-16). Siloxanes and other organic covering compounds are being explored (17). The electrolytic covering of the pyrite surface for passivation purposes (18) and synthetic resins to protect pyrite museum specimens from the sunlight and UV radiation (19) are additional interesting suggestions. These proposals reduce the oxidation rate of iron sulphides but not enough to allow a procedure of industrial 
como procedimiento de aplicación industrial para la inhibición de la oxidación. Evangelou abrió una patente con su método (20), pero después no fue licenciada industrialmente. Hoy en día los compuestos más utilizados para proteger la piedra natural de la alteración son los siloxanos, resinas orgánicas y poliuretanos, estando la investigación específica sobre pizarra centrada en estos compuestos application for the oxidation inhibition. Evangelou registered a patent with its method, but was later not licensed industrially (20). Nowadays, the most used compounds to protect the natural stone against the weathering are siloxanes, organic resins and polyurethanes. In the specific case of the roofing slate these compounds are also in the cutting edge of research.

\section{MECANISMOS DE ALTERACIÓN DE SULFU- ROS DE HIERRO}

La reacción de oxidación de la pirita se puede expresar como (10) [1-3]:

\section{MECHANISMS FOR THE IRON SULPHIDES WEATHERING}

The oxidation reaction for pyrite can be described as follows (10) [1-3]:

$$
\begin{aligned}
& \mathrm{FeS}_{2}+7 / 2 \mathrm{O}_{2}+\mathrm{H}_{2} \mathrm{O} \rightarrow \mathrm{Fe}_{2}++2 \mathrm{SO}^{2-}{ }_{4}+2 \mathrm{H}+ \\
& 4 \mathrm{Fe}^{2+}+\mathrm{O}_{2}+4 \mathrm{H}^{+} \rightarrow 4 \mathrm{Fe}^{3+}+2 \mathrm{H}_{2} \mathrm{O} \\
& \mathrm{FeS}_{2}+14 \mathrm{Fe}^{3+}+8 \mathrm{H}_{2} \mathrm{O} \rightarrow 15 \mathrm{Fe}^{2+}+16 \mathrm{H}^{+}+2 \mathrm{SO}^{2-}{ }_{4}
\end{aligned}
$$

Mientras que para la pirrotina se puede formular (13) [4]: Meanwhile for the pyrrothite case, the reaction is (13) [4]

$$
\mathrm{Fe}_{1-\mathrm{x}} \mathrm{S}+7 / 2 \mathrm{H}_{2} \mathrm{O} \rightarrow(1-\mathrm{x}) \mathrm{Fe}^{3+}+\mathrm{SO}^{2-}{ }_{4}+\mathrm{H}^{+}+3 \mathrm{H}_{2} \mathrm{O}
$$

Estas reacciones son endotérmicas, ya que necesitan una energía de activación mínima y presencia inicial de $\mathrm{O}_{2} \mathrm{o}$ $\mathrm{Fe}^{2+}$. Una vez que la reacción ha empezado, se retroalimenta hasta que se acaba el suministro de $\mathrm{Fe}^{2+}$. En condiciones atmosféricas constantes, la tasa empírica de oxidación de $\mathrm{Fe}^{2+}$ a $\mathrm{Fe}^{3+}$ tiene un periodo de vida media de 15 años para un pH comprendido entre 2,2 y 3,5 (21). Para valores de pH por debajo de 4 la oxidación se acelera por la aparición de bacterias como Thiobacillus Ferrooxidans o Leptospirillum Ferrooxidans (11), siendo la oxidación bioinducida muy importante en condiciones de $\mathrm{pH}$ ácido. Se pueden distinguir dos mecanismos fundamentales de oxidación bacteriana, oxidación directa, en la cual el organismo oxidante y la superficie del sulfuro de hierro están en contacto, e indirecta, donde el organismo genera $\mathrm{Fe}^{3+}$ en el medio sin entrar en contacto con el sulfuro de hierro. La reacción de oxidación bacteriana directa se puede expresar mediante [5]:

$$
\mathrm{FeS}_{2}+\mathrm{O}_{2} \rightarrow \mathrm{Fe}^{2+}+2 \mathrm{SO}^{2-}{ }_{4}+\mathrm{H}^{+}
$$

Siendo las reacciones intermedias [6 y 7$]$ :

$$
\begin{aligned}
& \mathrm{FeS}_{2} \rightarrow \mathrm{Fe}^{2+}+\mathrm{S}^{2-}{ }_{2} \\
& \mathrm{~S}^{2-}{ }_{2}+4 \mathrm{O}_{2} \rightarrow 2 \mathrm{SO}^{2-}{ }_{4}
\end{aligned}
$$

Being the intermediate reactions as follows [6 and 7]:

Al analizar con microscopía electrónica, se observa directamente la aparición de grietas y agujeros de corrosión sobre la superficie del mineral (10). En el caso del mecanismo de oxidación bacteriana indirecta, las reacciones son las siguientes [8 y 9 ]:

$$
\begin{aligned}
& \mathrm{FeS}_{2}+\mathrm{Fe}_{2}\left(\mathrm{SO}_{4}\right)_{3} \rightarrow 3 \mathrm{FeSO}_{4}+2 \mathrm{~S}^{0} \\
& 2 \mathrm{~S}^{0}+6 \mathrm{Fe}_{2}\left(\mathrm{SO}_{4}\right)_{3}+8 \mathrm{H}_{2} \mathrm{O} \rightarrow 12 \mathrm{FeSO}_{4}+8 \mathrm{H}_{2} \mathrm{SO}_{4}
\end{aligned}
$$

Los minerales resultantes de estas reacciones son jarosita potásica $\left[\mathrm{KFe}_{3}\left(\mathrm{SO}_{4}\right)_{2}(\mathrm{OH})_{6}\right]$, goetita $[\mathrm{FeOOH}]$, schwertmanita $\left[\mathrm{Fe}_{8} \mathrm{O}_{8}(\mathrm{OH})_{6} \mathrm{SO}_{4}\right]$ y azufre elemental, entre otros (22).
The resulting minerals obtained from these chemical reaction are potassium jarosite $\left[\mathrm{KFe}_{3}\left(\mathrm{SO}_{4}\right)_{2}(\mathrm{OH})_{6}\right]$, goethite $[\mathrm{FeOOH}]$, schwertmanite $\left[\mathrm{Fe}_{8} \mathrm{O}_{8}(\mathrm{OH})_{6} \mathrm{SO}_{4}\right]$ and nati- 
Los sulfuros de hierro que se encuentran en las pizarras para cubiertas del Sinclinal de Truchas (Galicia) son, por lo general, una mezcla de mono- y disulfuros de hierro. Únicamente en los cubos de pirita bien cristalizados (Figura 2a) se encuentra una única fase de disulfuros. Esta mezcla se debe al hecho de que la pirrotina es precursora de la pirita. Los sulfuros de hierro de origen sedimentario se forman por reacción del $\mathrm{H}_{2} \mathrm{~S}$, generado por descomposición de la materia orgánica con minerales de hierro, formando en primer lugar, FeS, que, a su vez, reacciona con $\mathrm{S}^{0}$ para dar lugar a $\mathrm{FeS}_{2}$ (23). La alterabilidad de los sulfuros de hierro es función de su especie mineralógica, ya que minerales monosulfuro como la pirrotina $\left(\mathrm{Fe}_{(1-x)} \mathrm{S}\right)$ tienen una estructura atómica hexagonal más desordenada y son más alterables que los bisulfuro como la pirita $\left(\mathrm{FeS}_{2}\right)$, que tiene estructura cúbica más ordenada (24-26). En la alteración también influye la ve sulphur, among others (22). The iron sulphides found in roofing slates from the Truchas sincline (Galicia) are mixtures of iron mono- and di-sulphides. The well-crystallized pyrite cubes (Figure 2a) only shows one phase of di-sulphides. These mixtures are explained since pyrrothite is a precursor of the iron-sulphide of pyrite. In sedimentary geological environments, iron sulphides form by reaction between the iron minerals and the $\mathrm{H}_{2} \mathrm{~S}$ generated by decomposition of the organic matter. In these cases, FeS is firstly formed, which finally reacts with $S^{0}$ to become $\mathrm{FeS}_{2}$ (23). The iron sulphides weathering depend on the environmental conditions (e.g., type of $\mathrm{pH}$, excessively salted environments, supply of oxygen and $\mathrm{Fe}^{3+}$ ) (12) but also on the mineralogical specimen. Mineral mono-sulphides such as the pyrrothite have a hexagonal but disordered atomic structure, which is more alterable than the cubic ordered lattice of the bisulphide phase of



Figura 2. Fotomicrografías tomadas el microscopio electrónico de barrido: (a) cubos de pirita en pizarra de Valdeorras sin alterar. (b) Cristales monoclínicos de yeso formados durante el ensayo de ataque de gas $\mathrm{SO}_{2}$ a una pizarra con $\mathrm{CaCO}_{3}$ Figure 2. Photomicrographs taken under electron microscope: (a) fresh pyrite cubes in Valdeorras slate. (b) Formation of monoclinic crystals of gypsum during the test of $\mathrm{SO}_{2}$ gas on a slate with $\mathrm{CaCO}_{3}$.

disponibilidad de oxígeno, $\mathrm{Fe}^{3+}$, el pH del medio (12) y las condiciones medioambientales de uso (ambientes excesivamente salinos). Otro factor importante es la morfología de los agregados cristalinos, ya que cuanto mayor sea la superficie específica de los mismos, más sensible será frente a los procesos oxidativos, con mayor área disponible para la interacción con el medio ambiente (27). Los agregados framboidales tienen una superficie específica mucho mayor que los agregados cúbicos y presentan mayores tasas de oxidación. En placas de pizarra, las alteraciones puntuales sin difusión por la superficie de la pizarra, se corresponden generalmente con alteración de pirita, con estructura cúbica, mientras que los regueros de óxido suelen ser debidos a pirrotina. Estos tipos de oxidación se corresponderían con los grados T1 y T2 del ensayo de ciclo térmico según la norma UNE 123262:2000, apartado 16 (28). En el caso de las impurezas de the pyrite $\left(\mathrm{FeS}_{2}\right)$ (24-26). The crystalline-aggregates morphology is also an important factor: aggregates with more specific surface implies more reaction area for weathering, and therefore, they are more sensitive to the oxidation processes (27). Framboid aggregates offer more specific surface in respect to the cubic aggregates with lower oxidation rates. In the slate plates, the isolated oxidation dots can be associated with pyrite, while the iron-oxidized pouring stains are possibly related with pyrrothite. This oxidation types could be classified with grades $T 1$ and $T 2$ of the test of thermal cycles described in the norm UNE 12326-2:2000, apdo 16 (28). In the case of limestone impurities $\left(\mathrm{CaCO}_{3}\right)$ the Spanish slates rarely surpass the amount of $1 \%$. However, marketable slates from Italy or China display circa $20 \%$ of limestone and can be considered a mixture between slate and limestone. The alteration products of $\mathrm{CaCO}_{3}$ are formed 
carbonatos, la pizarra española raramente supera el $1 \%$ de contenido, mientras que en pizarras chinas e italianas se han observado contenidos superiores al $20 \%$, por lo que desde un punto de vista petrográfico serían margas calcáreas en lugar de pizarras. Las alteraciones resultantes son debidas a la descomposición del carbonato $\left(\mathrm{CaCO}_{3}\right)$ presente para formar yeso $\left(\mathrm{CaSO}_{4}+\mathrm{H}_{2} \mathrm{O}\right)$ en presencia de azufre según la reacción [10]:

$$
\mathrm{CaCO}_{3}+\mathrm{H}_{2} \mathrm{SO}_{4} \rightarrow \mathrm{CaSO}_{4}+\mathrm{H}_{2} \mathrm{O}+\mathrm{CO}_{2}
$$

Este tipo de alteraciones se origina sobre todo en ambientes urbanos, donde las concentraciones de $\mathrm{SO}_{2}$ son mayores, y siempre y cuando la pizarra tenga carbonatos en su composición. La alteración característica aparece como eflorescencias blanquecinas de yeso (Figura 2b) sobre la superficie de la pizarra, que en los casos más extremos llegan a afectar a la cohesión superficial de la pizarra. Una colocación defectuosa de la pizarra en la cubierta puede llegar a producir este tipo de manchas blanquecinas. En el caso de utilizarse una capa de mortero de yeso sobre la estructura de forjado de la cubierta, si la colocación no se realiza de manera correcta, el agua puede llegar a filtrar lixiviando la capa de mortero, y manchando la superficie de las pizarras al correr sulfato sobre ellas.

\section{PRODUCTOS PROTECTORES PARA PIZA- RRAS}

Un producto protector aplicable para pizarra de cubiertas tiene que cumplir dos requisitos fundamentales: (i) no alterar el aspecto natural de la pizarra y (ii) protegerla de forma efectiva contra la alteración. Además, tiene de cumplir las condiciones siguientes: (1) servir como protección eficaz frente a los crecimientos de hongos y líquenes; (2) proteger a la pizarra frente a la oxidación durante al menos 10 años; (3) representar menos del $1 \%$ de la pieza total en volumen, o bien cumplir con la norma EN 13501 sobre reacción al fuego (29). Es muy importante que la superficie impregnada con el producto ofrezca un coeficiente de rozamiento alto, incluso en húmedo, para reducir al máximo el riesgo de resbalones del operario durante el proceso de colocación en la cubierta.

Actualmente, casi todos los productos que se utilizan para proteger la piedra natural son resinas de siliconas (silanos y siloxanos) y resinas fluorosiliconadas. Estas resinas se componen de largas cadenas de silicio-oxígeno polimerizados en las que se pueden incluir los grupos de moléculas que se requieran. En el caso de las resinas fluorosiliconadas se añade un grupo fluoro, que le confiere al polímero propiedades hidrofugantes y antimanchas. Estos compuestos penetran en los poros de la roca, orientándose con la parte hidrófuga de su molécula hacia el exterior. Para ello, el tamaño del poro ha de ser superior al tamaño de la molécula, con el fin de que ésta se by reaction with sulphate ions producing gypsum $\left(\mathrm{CaSO}_{4}\right.$ $+\mathrm{H}_{2} \mathrm{O}$ ) for instance [10]:
This type of weathering is produced on the slates with $\mathrm{CaCO}_{3}$ of urban environments, which are rich in $\mathrm{SO}_{2}$ due to the combustion of vehicles and central heaters. The resultant weathering products are whitish spots (Figure 2b) that look as gypsum efflorescence onto the slate outer but in some severe cases the external cohesion of the slate can be damaged. In addition, wrong settlements of slate tiles on the roof can produce this type of white stains, e.g., special attention must be observed using gypsum-mortars on the roof to prevent undesired lixiviation of $\mathrm{CaSO}_{4}$ along the roofing slate.

\section{TESTING PRODUCTS FOR SLATE PROTEC- TION}

A protective-covering product for roofing slate must fulfil two essential requirements: (i) it cannot change the natural aspect of the slate and (ii) must protect the slate of weathering. In addition, it is subject to the following conditions: (1) Perform a protection cover against fungi and lichens; (2) Perform a protection cover to prevent the oxidation during at least 10 years; (3) The covering product must be less than the $1 \%$ of the total volume of the tile, or fulfils the norm EN 13501 on reaction to the fire (29). Furthermore, it is crucial that the surface impregnated with the product displays a high coefficient of friction, even in humid conditions, to reduce the slides risk of workers on the roof.

Nowadays, almost all products used to protect natural stone are silicone or fluorosilicone resins, i.e, xylan and siloxane. These silicon resins are made up of long chains of polymerised silicon-oxygen in which external molecule groups can be included. In the case of silicon polymer resins, an additional fluoro group is added to provide waterproof and anti-stain characteristics to the polymer. These compounds penetrate in the rock pores with the waterproof part of their molecule facing outside. Obviously, to allow the way in of the product, the size of the pore must be larger than the molecule. In the group of the silicone resins, the small size of the molecules of 
pueda introducir. Dentro del grupo de las resinas de siliconas, los silanos se caracterizan por tener moléculas de pequeño tamaño (diámetro de $1,0 \times 10^{-6}$ a 1,5 x 10-6 milímetros), por lo que presentan alta movilidad y volatilidad, lo que facilita su penetración en la superficie de la roca, mientras que los siloxanos son un poco más voluminosos (diámetro de 1,5 x 10-6 a 7,5 x 10-6 milímetros). Las resinas epoxy y los poliésteres se usan sobre todo en mármol y rocas porosas, pero únicamente para pegar y sellar, ya que al ser completamente sólidos no presentan retracción y además amarillean con los rayos UV. Recientemente se está investigando el uso de poliuretanos en piedra natural; son muy resistentes frente a los factores ambientales, y en especial a los rayos UV, pero tienen un precio elevado.

\section{PROTOCOLO DE VALORACIÓN DE PRO- DUCTOS PROTECTORES}

El protocolo que se propone aquí ha sido desarrollado en el Centro Tecnológico de la Pizarra de Sobradelo de Valdeorras; consta de dos etapas, una, visual, donde se valora el aspecto, y otra, cualitativa, donde se valora la validez de la protección, por este orden, ya que se entiende que si un producto altera de manera significativa el aspecto externo de la pizarra, comercialmente no es válido a pesar de que pueda llegar a proteger contra la oxidación, por lo que ya no tiene sentido que se le someta a la siguiente batería de ensayos.

\section{Muestreo}

El muestreo de las pizarras ha de realizarse escogiendo pizarras lo más iguales posible, a ser posible provenientes del mismo bloque (rachón) para eliminar cualquier error atribuible a heterogeneidades de la muestra. La pizarra debe tener abundancia de elementos alterables, tales como sulfuros de hierro y carbonatos Generalmente este tipo de pizarra se suele desechar, o comercializar como $3^{a}$ clase o económica. Es importante que esto sea así, ya que la pizarra en la cual se empleará el tratamiento de protección será de calidad ECO (económica), no tendría sentido aplicar un tratamiento en una pizarra de primera calidad que no presenta problemas de alteración. También es recomendable incluir muestras de pizarra sin producto en cada ensayo, o bien aplicar el producto sólo por una cara, para comparar la intensidad de las alteraciones en la pizarra natural con las que se pudieran producir en la pizarra impregnada.

\section{Estación de tratamiento}

Por lo general, el proceso de impregnación del producto se realizará mediante una estación de tratamiento. Una estación de tratamiento estándar consta de las siguientes partes (Figura 3): xylans (diameter of $1.0 \times 10^{-6}$ to $1.5 \times 10^{-6}$ millimetres) allows high mobility and volatility, which facilitates its penetration in the rock surface, whereas siloxanes are larger (diameter of 1.5 xs $10^{-6}$ to 7.5 xs $10^{-6}$ millimetres). Epoxy resins and polyesters are mainly used in marble and porous rocks but only for sealing applications, because as completely-solid masses, they do not display retraction and turn yellow under UV-irradiation. Recently, the application of polyurethane on natural stone is being evaluated since it is very resistant to weathering, particularly to UV-irradiation. Unfortunately it is an expensive raw material.

\section{PROTOCOL TO EVALUATE PROTECTIVE PRODUCTS}

The protocol here proposed has been developed in the Technological Centre of the Slate, Sobradelo de Valdeorras. The protocol is composed of two stages, (1) visual, to appreciate the general aspect and (2) qualitative, to value the validity of the protection. The order of the two-stage protocol is deliberate. If the product evaluated clearly modifies the external aspect of the slate, it is not commercially valid although it can get protection against oxidation. This crucial condition rejects the product saving the further tests sets.

\section{Sampling}

The slate tile sampling must be made choosing homogeneous specimens coming from the same block to prevent errors of sample heterogeneities. The selected specimen must show many alterable elements such as iron sulphides or carbonates. Generally, this kind of slate is rejected or sold as $3^{a}$ economic class. It is important to perform this selection, since the slate in which the protection treatment will be placed will be of quality ECO (economic class). It is not reasonable to apply the treatment to first quality slates without potential weathering problems. We suggest to include slate samples without product in each test, or to apply the product in one of the two faces of the tile, to compare both weathering features in natural and treated slate.

\section{Treatment place}

The impregnation of the product is commonly made together with the industrial process of the slate tiles. The treatment place is composed by the following elements (Figure 3): 


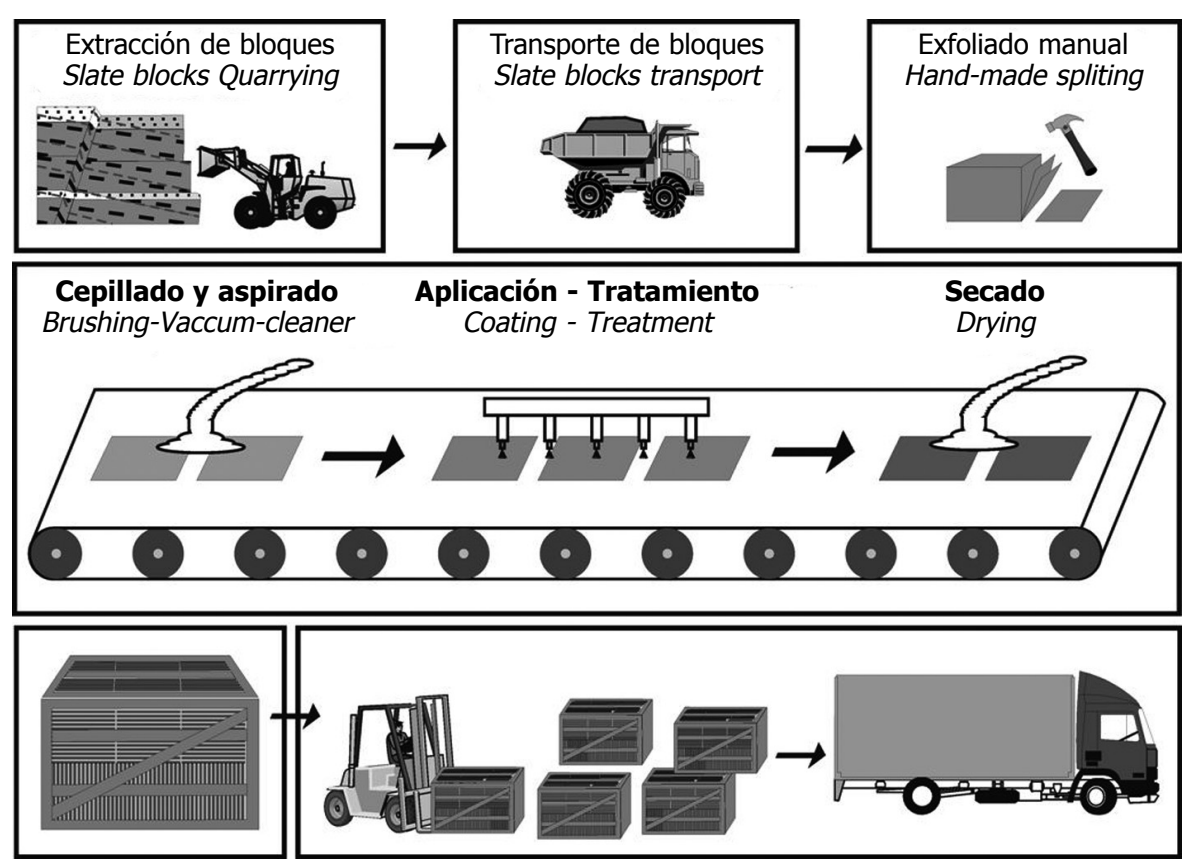

Figura 3. Procesos de extracción minera y manufactura industrial de la pizarra de techar incorporando los nuevos tratamientos de impregnación.

Figure 3. Processes of mining extraction and industrial manufacture of roofing slate to incorporating the new coating treatments.

1.- Entrada de piezas de pizarra ya recortadas.

2.- Cepillado y aspirado de las pizarras, para obtener una superficie lo más limpia posible.

3.- Aplicación del producto, bien por difusión mediante boquillas o por nebulización en cámara cerrada. En cualquier caso, los cantos de la pizarra también deben ser aplicados.

4.- Secado de las piezas mediante horno ventilado de baja temperatura o rayos UV.

5.- Flejado y embalado de las piezas en jaulas.

\section{Etapa 1. - Valoración visual}

Se cuantifica de forma numérica el aspecto de la placa de pizarra una vez aplicado el producto, para lo cual se utiliza el modelo de cuestionario adjunto, dando la puntuación indicada al lado de la calificación observada en cada apartado. Los formatos de pizarra que se utilizarán serán placas de 30×20 ó 32×22 centímetros.

A) - Cambios de color en la placa:

7 Ninguno

5 Ligero cambio de color

3 Moderado cambio de color

0 Marcado, cambio de color

B) - Alteraciones de brillo en la placa:

7 Ninguna

5 Disminución del brillo natural de la pizarra
1.- Entrance of slate pieces already shaped.

2.- Brushing and vacuum to clean the surface.

3.- Coating of the slate tile with the product by pneumatic vaporization in closed chamber. Edges of the slate tile must also be coated.

4.- Drying of the pieces in open furnace at low temperature or under rays UV.

5.- Boxing and shrink wrapped onto wooden pallets locked with stainless steel strips.

\section{Stage 1. - Visual examination}

The aspect of the slate tile, once coated, is quantified by a numerical method using the enclosed questionnaire model. The slate size formats are plates of $30 \times 20$ or $32 \times 22$ centimetres.

A) - Colour changes observed in the tile:

7 Not observed

5 Minor colour changes

3 Intermediate colour changes

o Major colour changes

B) - Brightness changes observed in the tile:

7 Not observed

5 Reduction of the natural brightness 
3 Aumento del brillo natural, aspecto plastificado

0 Gran aumento del brillo natural, aspecto mojado

C) - Resistencia del producto a las marcas producidas por el roce y/o embalaje:

2 Sin marcas apreciables

1 Menos de 15 marcas por cara

0 Más de 15 marcas por cara

D) - Coloraciones propias del producto en la placa, irisaciones:

2 Ninguna

0 Coloración en los bordes y/o la superficie de la placa

E) - Descamaciones y burbujas del producto en la superficie de la placa:

2 Ninguna

0 Descamaciones y/o burbujas apreciables a simple vista

Los apartados A y B, referentes al color y brillo, son los que tienen mayor importancia. Para efectuar estas comparaciones se observan dos superficies de pizarra, una tratada y otra sin tratar, con luz natural indirecta y a una distancia mínima de dos metros. En el caso de que se quieran obtener imágenes de las pizarras, se recomienda utilizar escáner en lugar de cámara digital, ya que el escáner mantiene siempre las mismas condiciones de exposición e iluminación en todas las imágenes, y la cámara digital puede variar dichas condiciones, sobre todo si la iluminación no es la correcta. El apartado A hace referencia a los cambios de color (Figura 4A-1-2) que puedan aparecer en la superficie de la placa, teniendo en cuenta la distancia mínima a la que se pueden observar, ya que una vez colocada la pizarra en la cubierta, el aspecto general siempre mejora, a pesar de que pudiera haber alguna alteración en el color. Generalmente, estos cambios suelen consistir en oscurecimientos en la tonalidad de la pizarra, aunque determinados productos llegan a dar tonos azulados a la misma. Se entiende que el producto tiene que ser transparente para no alterar el color natural de la pizarra, aunque se han ensayado productos con una ligera pigmentación gris oscura que ayudan a disminuir brillos indeseados. Aunque el tono original de la pizarra no se mantenga idéntico, excepcionalmente se pueden aceptar otras coloraciones dentro de las tonalidades que acepta el mercado.

El apartado B, referido al brillo, es más complicado, ya que es normal que el brillo se vea incrementado al impregnar el producto, aunque hoy en día están surgiendo productos que confieren un tono mate y eliminan el brillo natural que tienen algunas pizarras debido a los filosilicatos. Dentro de este apartado se han distinguido cuatro grados, un primero en el que la pizarra no presentaría cambios en el brillo, un segundo en el que la pizarra
3 Increasing of the natural brightness with plasticized aspect 0 Strong increasing of the natural brightness and wet aspect

C) - Resistance of the product to the scratches produced by rubbing and/or package:

2 Without appreciable scratches

1 Less than 15 scratches by face

0 More than 15 scratches by face

D) - Intrinsic colourations of the product in the tile, rainbow effect

2 Not observed

0 Coloration in the edges and/or the surface of the tile

E) - Desquamation and bubbles of the product onto the tile surface:

2 Not observed

0 Desquamation and/or bubbles visible to the naked eye.

Sections $A$ and $B$, dealing with colour and brightness, are very important. In this aspect, it is necessary to compare two pieces of the same slate, fresh and treated, and then, to observe under indirect natural light from a distance beyond 2 metres away. Instead of taking pictures of the plates with a digital camera, it is recommended to scan the tiles, maintaining the same conditions of exhibition and illumination in all the images. Section $A$ describes possible changes of colour (Figure 4A-1-2) in the surface of the plate considering the minimum distance to which they are appreciable. Later, once placed the slate in the roof, the general look improves even if some alteration in the colour appears. These changes usually consist on darkening in the slate colour, although specific products could provide bluish colour to the slate. The product must be transparent to preserve the slate natural colour, even though some products with a light dark hue could reduce the undesired brightness. Although the original hue of the slate might not remain identical, exceptionally it can be used other hues accepted within the market.

Section $B$ is complex since it is usual that the brightness increases when applying the product. However, nowadays, arise products which provide plain hues, removing the natural brightness which many slates exhibit attributed to the phyllo-silicates. Within this visual section four degrees have been distinguished, as follows: (i) the slate would not display changes in the brightness, (ii) the slate loses its natural brightness due to the product, (iii) the 
pierde su brillo natural debido al producto, un tercero en el que la pizarra tendría el mismo aspecto que una superficie plana con un tratamiento protector plástico por encima, y un cuarto en el que la pizarra tendría aspecto mojado, como si corriera una fina lámina de agua por su superficie. La alteración del brillo tiene más importancia estética si éste se ve incrementado que si se ve reducido, y, por tanto, se tiene más en cuenta a efectos de la presente determinación (Figura 4B-1-2). slate looks like a flat surface with a plasticized covering outer, and (iv) the slate shows a wet aspect, as if a fine water lamina running by its surface. The brightness alteration has more aesthetic importance if it increases than if reduces. That reason has been considered in our visual test (Figure 4B-1-2).


Figura 3. Pares comparativos de placas de pizarra sometidas a los ensayos del protocolo propuesto: A1.-Pizarra natural de color más claro, A2.-Pizarra impregnada de color más oscuro; B1.-Pizarra natural sin brillo, B2.-Pizarra impregnada con más brillo; C.- Pizarra impregnada y rayada por el ensayo, D.-Pizarra impregnada y con descamaciones del producto protector producidas por el tratamiento térmico; E1.- Pizarra natural oxidada e impregnada, E2.- Pizarra natural oxidada sin impregnar; F1.- Imagen de alteraciones de pizarra, F2.- La misma imagen tratada con ImageJ freeware.

Figure 3. Comparison between slate plates after the application of the laboratory tests of the protocol here proposed: A1.- Natural slate of pale colour A2.- Impregnated slate of darker colour; B1.- Natural slate without brightness, B2.- Impregnated slate with brightness; C.Impregnated slate with the soft test scratches, D.- Impregnated slate with desquamations of the protective product after the test heating; E1.- Oxidized and impregnated natural slate, E2. - Oxidized natural slate without impregnation; F1.- Scanned Image of slate alterations, F2. - The same image anlyzed with IMAGEJ freeware.

El apartado $\mathrm{C}$ sirve para definir la resistencia del producto a los arañazos superficiales, para ello se frotan dos pizarras tratadas, en sentido circular cara contra cara diez veces, y se observan las marcas de rozamiento y arañazos resultantes. Estas marcas serán asumidas en el caso de que sean permanentes y no desaparezcan fácilmente al pasar la mano o un trapo por su superficie (Figura 4C). Respecto a una superficie de pizarra que presenta arañazos, la impregnación puede seguir siendo efectiva, pero desde un punto de vista estético y comercial es desaconsejable que se vean demasiadas raspaduras.
Section C informs on the product resistance to superficial scratches, by rubbing ten times in circular movements two treated slates against each other and testing their possible resulting new friction scratches. Only marks that are permanent and cannot be removed after a light cleaning are interpreted as scratches (Figure 4C). In despite of the resultant scratches the final product could be resistant, however, from an aesthetic point of view, and for marketable purposes we do not recommend the use of tiles with many scrapings. 
Los apartados $D$ y $E$ inciden en los posibles fallos que haya habido durante el proceso de aplicación: (i) Distribución del producto no es homogénea, generalmente atribuida a problemas con las boquillas difusoras. (ii) Gramaje inadecuado según las especificaciones del fabricante del producto, por lo que la protección podría no ser óptima. Un gramaje incorrecto se puede deber a una velocidad incorrecta de paso de las pizarras por la cámara de impregnación o a una mala calibración de las boquillas difusoras en el caso de que se hayan sido utilizadas. (iii) Mezcla del producto incorrecta en el caso de productos policomponentes, generalmente debido a fallos en el mecanismo de mezclado o acumulación de residuos en los conductos de salida de los componentes. (iv) Sistema de secado incorrecto, lo que puede hacer que las pizarras se embalen sin haber llegado a terminar el proceso de impregnación. Este tipo de defectos en el proceso de aplicación hace que el aspecto que muestre la pizarra no sea el adecuado, sin contar con que la eficacia de la protección puede no ser la esperada. Para comprobar estos dos apartados se observa la superficie de la pizarra a simple vista, poniendo especial atención en las zonas cercanas al borde.

El apartado D distingue entre las coloraciones que se pueden producir en los bordes o en la superficie, siendo debidas a deficiencias en el proceso de secado. Por lo general, estas coloraciones suelen acumularse en los bordes de la placa, o bien presentarse como manchas de aspecto oleaginoso o irisado en la superficie de la pizarra. También se puede deber a fallos en la aplicación del producto en los cantos.

El apartado E se refiere a las burbujas de aire y en general a heterogeneidades en la película que se puedan producir en la superficie de la pizarra debido a una mala aplicación. Una vez completados los cinco apartados, se suman todas las puntuaciones y se dividen por 2, de manera que se obtenga un valor del 0 al 10 , siendo el 0 el caso más desfavorable y el 10 el caso más favorable. Dependiendo del criterio de aceptación que se establezca inicialmente el producto pasará a la siguiente etapa, aunque se recomienda descartar productos con un índice inferior a 7.

\section{Etapa 2.- Ensayos de laboratorio}

Esta etapa se compone de tres ensayos encaminados a comprobar la eficacia protectora del producto y resistencia del mismo frente a los factores ambientales.

1 - Ciclo térmico modificado según norma UNE en 123262:2000, apartado 16 (28). Para este ensayo modificado no se pulen los cantos de las pizarras, como se indica en la propia norma UNE, ya que se eliminaría la protección en esa zona. Se propone sumergir las placas de pizarra en agua destilada a $(23 \pm 5){ }^{\circ} \mathrm{C}$ durante 6 horas, luego
Sections $D$ and $E$ concern to possible failures occurred during the impregnation process: (i) Not homogenous distribution of the product attributable to problems in the pneumatic vaporization process. (ii) Anomalous quantity of product impregnated in the slate according to the specifications of the product manufacturer. The wrong product weight can be the result of a wrong speed in the slates passage by the impregnating chamber or also of a calibration problem of the diffusing mouths. (iii) Incorrect mixture of poly-compounds products by failures in the mixing mechanism or accumulation of pipe relicts. (iv) Wrong drying in which the slates are boxed before completely finishing the impregnating process. This type of defects in the impregnation process could modify the slate aspect and the protection efficacy. To verify both sections, the slate surface will be observed, firstly focusing on the zones near the edge.

Section $D$ is referred to the colourations that are accumulated in the edges of the plate or appear as spots of oily or rainbow aspect onto the slate surface. These colourations can be produced by deficiencies in the drying process, but also can be a consequence of failures in the application of the product.

Finally, the section E inform on air bubbles and heterogeneities in the film, which can be produced in the slate surface by incorrect dissemination of the product. Once completed the five sections, the scores obtained must be added and divided by 2; the resultant value ranges from 0 to 10 , being the 0 the most unfavourable case. Depending on the acceptance number, previously stated, the product will moves to the following stage, although it is recommended discard products with index worse than 7.

\section{Stage 2.- Laboratory tests}

This step is composed by three different experiments testing the protective efficiency and resistance of the product under environmental weathering.

1 - Thermal cycle modified from norm UNE EN 123262:2000, apd. 16 (28). To perform this test the edges were not polished as norm UNE describes since the polishing action removes the protective product in this zone. The procedure starts sinking the slate plates in distilled water at $(23 \pm 5)^{\circ} \mathrm{C}$ for 6 hours. Later, the plates remain 
introducirlas en estufa ventilada a $(110 \pm 5){ }^{\circ} \mathrm{C}$ durante 17 horas, y finalmente 1 hora de enfriado a temperatura ambiente. Esta secuencia constituye 1 ciclo, siendo 20 ciclos los indicados en la norma UNE. Al cabo de 20 ciclos se le otorga de manera visual un valor a cada placa, siendo T1 oxidación superficial de minerales metálicos, T2 oxidación o cambios en el aspecto externo de las inclusiones metálicas con bandas de decoloración, y T3 oxidación o cambios en el aspecto externo de los minerales metálicos que penetran la pizarra, con el riesgo de formar agujeros.

Éste es el único ensayo válido para predecir la oxidación según la normativa UNE. Por lo general, no se aceptan agrietamientos o descamaciones en el producto después del ciclo térmico (Figura 4 D). Sin embargo, este ensayo presenta el inconveniente de la temperatura, ya que hay productos protectores que se degradan rápidamente por encima de los $80^{\circ} \mathrm{C}$, lo que no quiere decir que no sean efectivos para proteger en el tiempo. La temperatura máxima que puede llegar a alcanzar una placa de pizarra colocada en una cubierta mediante radiación solar es un dato que aún no se conoce con precisión, pero en ningún caso debería ser superior a $80^{\circ} \mathrm{C}$, como sugiere la medición continua automática de temperatura que se está llevando a cabo en el Centro Tecnológico de la Pizarra de Sobradelo de Valdeorras. Para comprobar el efecto de la temperatura en el ciclo térmico se realizó el siguiente experimento. Se rebajaron los márgenes superior e inferior, a $80 \circ$ y $-20{ }^{\circ} \mathrm{C}$ respectivamente. Primeramente las pizarras se congelan a $(-20 \pm 5){ }^{\circ} \mathrm{C}$ durante 6 horas, luego pasan al agua destilada a $(23 \pm 5){ }^{\circ} \mathrm{C}$ durante 3 horas, para finalmente pasar a estufa ventilada a (80 \pm 5) ${ }^{\circ} \mathrm{C}$ durante 14 horas. El ciclo acaba con 1 hora de enfriado a temperatura ambiente. Al mismo tiempo que se llevó a cabo este ciclo alternativo, se hizo un ciclo térmico según norma UNE, utilizando en ambos ciclos la misma pizarra. El resultado muestra una mayor tasa de oxidación en las pizarras del ciclo térmico según norma UNE, por la influencia de la temperatura en la oxidabilidad. Con estos datos, se llega a la conclusión de que a pesar que el ciclo térmico, según norma UNE, pueda llegar a alterar la eficacia de la protección, se trata de la mejor herramienta que se dispone hoy en día para comprobar la oxidación de sulfuros de hierro en pizarras para techar, estén o no estén tratadas.

2 - Exposición al dióxido de azufre modificado según norma UNE EN 12326-2:2000, apartado 15.1 (28). Para pizarras con menos de un $20 \%$ de contenido en carbonato (en la práctica todas las pizarras españolas) se preparan seis probetas secadas en estufa ventilada a (110 \pm 5$)$ ${ }^{\circ} \mathrm{C}$ durante 24 horas, y otras seis probetas sumergidas en agua destilada a $(23 \pm 5){ }^{\circ} \mathrm{C}$ durante 24 horas. No se pulen los cantos, como indica la norma, para no eliminar la protección en esa zona. Como reactivo se utilizan dos in ventilated stove at $(110 \pm 5){ }^{\circ} \mathrm{C}$ for 17 hours, and finally the samples are cooled down to room temperature for 1 hour. This described sequence represent one cycle, and the norm UNE (28) proposes 20 identical cycles. After 20 cycles, each tile of slate is rated following a three-category visual examination: (T1) Surface oxidation of metallic minerals, (T2) oxidation or changes in the external aspect of the metallic inclusions which show decolouration rings, and (T3) oxidation or changes in the external aspect of the metallic inclusions which can even drill the plate and produce holes in the surface.

Following the norm UNE (28), this procedure is the only valuable test capable to forecast future oxidation. Generally, desquamations and fissures in the product formed during the thermal cycle are not accepted (Figure 4 $D)$. However, this test has the inconvenience that some protective products decay very fast beyond $80^{\circ} \mathrm{C}$, but in natural environments they are very protective and resistant. In accordance with the published data and our experimental measurements obtained in the Technological Center of the Slate (Sobradelo de Valdeorras, Ourense, NW Spain), the maximum temperature of slate tiles placed in roofs under sunlight remains still as a poorly know datum, nevertheless never could overpass $80^{\circ} \mathrm{C}$. To check the temperature effect in the thermal cycle an additional experiment was performed, reducing the lower and upper thermal limits up to $80^{\circ}$ and $-20^{\circ} \mathrm{C}$ respectively. Firstly the slate pieces were frozen at $(-20 \pm 5)^{\circ} \mathrm{C}$ for 6 hours, later were soaked in distilled water at $(23 \pm 5){ }^{\circ} \mathrm{C}$ for 3 hours, and finally were heated in open furnace at $(80 \pm 5){ }^{\circ} \mathrm{C}$ for 14 hours. The cycle ends with one hour cooling down to room temperature. Simultaneously, other thermal cycle was performed following the norm UNE (28) using, in both cycles, aliquots of the same slate block. The result shows a large oxidation rate in the slate aliquots following the norm $U N E$, suggesting that the oxidation of iron sulphides depends largely on temperature. In spite that the thermal cycle can deteriorate the protective coatings, the final conclusion is that the thermal cycle proposed by the norm UNE (28) is the best tool to test the oxidation rate of the iron sulphides in both types of roofing slates, natural and treated with protective coatings (Figure E-1-2).

2 - Exposition to sulphur dioxide modified according to norm UNE 12326-2: 2000, apt. 15.1 (28). For slates with less of a $20 \%$ of carbonate content (actually all the marketable Spanish slates) we prepared six test slate plates dried in a ventilated stove at $(110 \pm 5){ }^{\circ} \mathrm{C}$ during 24 hours, and other six test plates sunken in distilled water at $(23 \pm 5){ }^{\circ} \mathrm{C}$ for 24 hours. The slate edges were not polished, as the norm indicates, to prevent the protection removal. Two sulphurous acid solutions were used as 
soluciones de ácido sulfuroso, una solución $A$, preparada por disolución de 0,6 litros de ácido sulfuroso (5 - 6\%) en 0,18 litros de agua destilada, y una solución $B$, preparada por disolución de 0,18 litros de ácido sulfuroso (5 - 6 $\%$ ) en 0,6 litros de agua destilada. Se introducen tres placas secas y tres placas embebidas en agua en un recipiente herméticamente cerrado con la solución $A$, y las otras seis placas restantes en otro recipiente idéntico con la solución B en su interior, sin que en ambos casos las placas estén en contacto con las disoluciones. El ensayo dura 21 días, después de los cuales según la norma UNE se examinan las probetas para comprobar la existencia de roturas, hinchamientos o descamaciones, lo que sirve para otorgar un código S1, S2 o S3 dependiendo de si estos defectos aparecen en la solución más concentrada (solución A) o en la solución menos concentrada (solución B). Este ensayo, tal y como se plantea en la norma UNE, está más enfocado a comprobar la cohesión de la pizarra frente a la degradación en un ambiente urbano que a evidenciar la oxidabilidad de la pizarra. Sin embargo, en el caso de existir sulfuros de hierro o carbonatos en la pizarra, éstos se descomponen, en mayor o menor medida, dependiendo de su alterabilidad, por lo que este ensayo también proporciona este tipo de información. A efectos de determinar la validez de un producto, hay que aplicarlo sólo por una cara, quedando la otra al natural. Una vez finalizado el ensayo se comparan las alteraciones entre las caras tratadas y las naturales. El resultado de esta comparación relativa se expresará mediante tres grados: $A$; sin diferencias entre las alteraciones en las caras tratadas y las naturales, B; diferencias de color y brillo entre las alteraciones de sulfuros de hierro de las caras tratadas y las naturales, y C; diferencias de color y brillo, junto con aumento de volumen entre las caras tratadas y las naturales (Figura E-1-2). Las alteraciones de color blanquecino son crecimientos microscópicos de cristales de yeso debidos a pequeños contenidos previos en calcio, debiéndose indicar su aparición en el informe final.

3 - Determinación de la resistencia a condiciones cíclicas de corrosión. Humedad (niebla salina)/sequedad/humedad/rayos UV, modificado según UNE EN ISO 11997-2. (30-32). Este ensayo se utiliza para comprobar la resistencia a la corrosión en pinturas y barnices. Se utilizan dos tipos distintos de cámaras, una de envejecimiento por rayos UV y otra de corrosión cíclica, empezando el ensayo por este orden. La cámara de envejecimiento por rayos UV utiliza lámparas UV de 340 nanómetros, que reproduce de la mejor manera posible la radiación solar, aunque también se utilizan lámparas UV 313, con una radiación más intensa que la solar y que proporciona resultados más rápidamente (33-34). Las pizarras primero son irradiadas por las lámparas durante 4 horas a una temperatura de $(60 \pm 5)^{\circ} \mathrm{C}$ y después pasan a condiciones de condensación sin radiación UV durante otras 4 horas, siendo estos dos pasos un ciclo. Después de 21 reactive: solution $A$, prepared by dissolution of 0,6 litres of sulphurous acid $(5-6 \%)$ in 0.18 litres of distilled water, and solution $B$, prepared by dissolution of 0.18 litres of sulphurous acid (5 - 6\%) in 0.6 litres of distilled water. Three dried testing slate plates and three testing plates loaded with water were introduced in a container hermetically locked with the solution A. Other six testing plates were introduced in a second identical container with solution $B$. In both cases, the testing slate plates were hold in air, separated from the solutions that remain at the bottom of the containers. After 21 days, according to the norm UNE, the testing slate plates were examined checking possible fissures, swellings or desquamations, which it serves to assign a code S1, S2 or S3 depending on the defects quantity detected in the more concentrated solution $A$ or in the less concentrated solution B. In accordance with the norm UNE, this test is more focused to verify the cohesion of the slate under deterioration in urban atmosphere that to demonstrate the slate oxidation rate. Nevertheless, if iron sulphides or carbonates exist in the slate, these react more or less with the $\mathrm{SO} 2$ gas providing additional information. To validate a new product we suggest to infiltrate only one face of the plate for comparison purposes between both surfaces, i.e., natural and treated. The result of this relative comparison will be expressed by three grades: $(A)$ without differences between the alterations in both faces, $(B)$ differences of colour and brightness in iron sulphide alterations between the faces; and $(C)$ differences of colour and brightness, along with an increase of volume between natural and treated faces (E-1-2 Figure). Alterations of whitish colour which may emerge usually are microscopic growth of gypsum crystals by calcium contamination and they are not interesting for this determination.

3 - Determination of the resistance to cyclical conditions of corrosion. Humidity (saline fog) /dryness conditions, humidity, UV-irradiation, modified according to UNE en ISO 11997-2 (30-32). This test is used to verify the resistance to corrosion in paintings and varnishes. Two different types of chamber are used, one for aging samples by UV-irradiation and other for cyclical corrosion, beginning the test by this order. The chamber for aging slates under UV-irradiation uses UV lamps of $340 \mathrm{~nm}$ to reproduce the solar irradiation, although UV lamps of $313 \mathrm{~nm}$, with greater UV radiation than natural sunlight, are more effective and provides results more quickly (33-34). Slate plates are irradiated under UV lamps during 4 hours at $(60 \pm 5)^{\circ} \mathrm{C}$, later they suffer condensation conditions without UV-irradiation during other 4 hours, being these two steps a cycle. After 21 cycles, the next phase of cyclical corrosion starts. The treated slates are introduced in 
ciclos se pasa a la fase de corrosión cíclica, para lo cual se introducen las pizarras tratadas en una cámara donde primero se nebuliza una disolución de cloruro sódico en agua a (35 \pm 5 ) ${ }^{\circ} \mathrm{C}$ durante 2 horas, después se pasa a condiciones de sequedad con un $20-30 \%$ de humedad relativa durante 4 horas, y finalmente se aumenta la humedad por encima del $95 \%$ durante 2 horas, comprendiendo estas tres etapas un ciclo completo de 8 horas. Las placas permanecen en esta cámara otros 21 ciclos. En total cada ciclo de envejecimiento-corrosión consta de 14 días, repitiéndose estos ciclos 3 veces, hasta las seis semanas o 1.008 horas en total. Una vez acabado el ensayo, se clasifican las pizarras según el grado de alteración que presenten, para lo cual se utiliza un programa de tratamiento de imágenes que analiza la superficie y calcula el porcentaje de área alterada. Se ha utilizado el programa libre ImageJ del National Institutes of Health (EEUU). (Figura F-1-2) (35). La imagen tiene que ser transformada a escala de grises de 8 bits y el umbral de detección se establece de manera que queden cubiertas las zonas alteradas tomando como referencia la imagen original.

Los grados de alteración son los siguientes (en porcentaje de superficie alterada):

$$
\begin{aligned}
& \text { Grado 1: } 0,00-4,99 \% \\
& \text { Grado 2: 5,00 - } 14,99 \% \\
& \text { Grado 3: } 15,00-49,00 \% \\
& \text { Grado 4: } 50,00-100,00 \%
\end{aligned}
$$

Por lo general, se considera que un producto es conforme con un grado de alteración 1, aunque la evaluación final dependerá de los criterios fijados previamente.

\section{Ejemplo de aplicación}

El presente protocolo se aplicó en dos productos comerciales, A y B, frecuentemente utilizados en piedra natural. El producto $A$ es un hidrofugante a base de siloxanos, y el producto $B$ es silicato potásico utilizado para consolidar y proteger monumentos históricos. Cada producto se aplicó con difusor manual sobre un grupo de 9 placas de pizarra de $32 \times 22$ centímetros, impregnando una cara y dejando la otra natural como control. Se pesaron todas las placas antes y después de la aplicación para conocer el gramaje medio, siendo de $19,3 \mathrm{~g} / \mathrm{m}^{2}$ para el producto A y $21,3 \mathrm{~g} / \mathrm{m}^{2}$ para el producto $B$. Las placas se secaron en estufa ventilada a $60^{\circ} \mathrm{C}$ durante 24 horas, después de las cuales se hizo la valoración visual. El producto A presentó un ligero cambio de color en la placa y disminución del brillo natural, junto con algunas marcas (inferiores a 15) producidas al frotar una superficie contra otra, lo que le otorga una puntuación de 7,5. El producto $B$ alteró de manera significativa el aspecto de la placa, dándole un tono azulado con zonas blanquecinas y con disminución del brillo, junto con coloraciones en la superficie de la a chamber with a pulverised dissolution of sodium chloride in water at ( $35 \pm 5)^{\circ} \mathrm{C}$ during 2 hours, later the samples are exposed to dryness conditions with $20-30 \%$ of relative humidity during 4 hours, and finally, the humidity is increased to over $95 \%$ during 2 hours. These three stages cover a complete cycle of 8 hours. The testing plates remain in this chamber other 21 cycles. Each cycle of aging-corrosion lasts 14 days. The cycles are repeated 3 times, and the complete test lasts up to six weeks or a total of 1,008 hours. Once the test is finished, slates are classified according to the resultant alteration grade, for which is used a freeware software of treatment of images that analyses the surface and calculates the percentage of altered area. We used the freeware program IMAGEJ of the National Institutes of Health (EEUU) (Figure F1-2) (35). The coloured image must be converted to the greyscale format of 8 bits and the threshold is established keeping totally covered all the altered zones using the original image a reference pattern.

The alteration grades are as follows: (Percentage of altered surface):

Grade 1: $0.00-4.99 \%$

Grade 2: $5.00-14.99 \%$

Grade 3: $15.00-49.00 \%$

Grade 4: $50.00-100.00 \%$

Roughly it is considered that a product is in agreement with an alteration grade 1 , although the final evaluation will depend on the criteria fixed previously.

\section{Application example}

The present protocol was applied in two commercial products, named $A$ and $B$, frequently used in natural stone. The product $A$ is a water-repellent based on siloxanes. The product $B$ is potassium silicate, used to consolidate and protect historical monuments. Each product was applied with a manual spray gun on a group of 9 tiles of slate, impregnating one surface and leaving the other one as control. All the tiles were weighed before and after the application to know the product weight, being of 19,3 $\mathrm{g} / \mathrm{m}^{2}$ for the product $A$ and $21,3 \mathrm{~g} / \mathrm{m}^{2}$ for the product $B$. The tiles were dried off in a ventilated stove to $60{ }^{\circ} \mathrm{C}$ during 24 hours, after which the visual valuation was made. The product $A$ presented a slight colour changes in the surface and decrease of the natural brightness, together with some marks (less than 15) taken place when rubbing a surface against other, which means an index of 7,5. The product $B$ altered in a significant way the aspect of the tile, showing a blue hue with whitish areas and decrease of the brightness, together with colourations in the surface, and obtaining an index of 4. 
placa, lo que le otorga una puntuación de 4 . Con estos resultados, solo pasaría a la etapa 2 el producto $A$, pero a efectos del presente trabajo el producto $B$ pasó también a la siguiente etapa. Los ensayos de exposición al dióxido de azufre y ciclo térmico se llevaron a cabo en el Centro Tecnológico de la Pizarra, Ourense, y el ensayo de exposición a niebla salina se llevó a cabo en el Centro Tecnológico del Granito, Pontevedra. Los resultados de los ensayos se muestran en la Figura 5. Ninguno de los dos productos cumple con los requisitos fijados para ser aplicado eficazmente en placas de pizarra para cubiertas.
With these results, only the product $A$ would pass to stage 2 , but for the present work the product $B$ also passed to the following stage. The exposition to sulphur dioxide and thermal cycle tests were carried out in the Technological Center of the Slate, Ourense, and the exposition test to saline fog was carried out in the Technological Center of the Granite, Pontevedra. The results of these tests are shown in the Figure 5. None of the two products fulfilled the requirements fixed to be applied efficiently in roofing slate, which is a logical result, as these products were not formulated to be applied in slate tiles.

Figura 5. Resumen de resultados del ejemplo de aplicación.

Figure 5. Summarized results of the application example.

\begin{tabular}{|c|c|c|c|c|}
\hline & \multirow{2}{*}{\begin{tabular}{|c|} 
Etapa 1 \\
Stage 1 \\
Valoración visual \\
Visual examination \\
\end{tabular}} & \multicolumn{3}{|c|}{$\begin{array}{l}\text { Etapa } 2 \\
\text { Stage } 2 \\
\end{array}$} \\
\hline & & $\begin{array}{l}\text { Ciclo Térmico } \\
\text { Thermal Cycle }\end{array}$ & $\begin{array}{l}\text { Exposición } \mathrm{SO}_{2} \\
\text { Exposition } \mathrm{SO}_{2} \\
\end{array}$ & $\begin{array}{c}\text { Niebla salina } \\
\text { Saline fog }\end{array}$ \\
\hline Producto A & 7.5 & $\mathrm{~T} 2$ & grado/grade S1 & grado/grade 2 \\
\hline Producto B & 4.0 & T2 & grado/grade S1 & grado/grade 3 \\
\hline
\end{tabular}

\section{CONCLUSIONES}

El presente protocolo pretende llenar el vacío existente actual para evaluar un producto protector para pizarra para cubiertas. Hasta hace muy poco la industria pizarrera no se preocupaba por encontrar un remedio efectivo a las alteraciones que pueden sufrir algunas pizarras a lo largo de su vida útil. El desarrollo de dichos productos requiere una herramienta de diagnóstico válido de su eficacia. La combinación de los ensayos tecnológicos aquí descritos junto con el cuestionario visual propuesto permite otorgar un índice de calidad. Cada uno de los tres ensayos propuestos en este protocolo utiliza una propiedad del tratamiento importante en pizarras: (i) Ciclo térmico. Resistencia frente a la oxidación de los sulfuros de hierro. (ii) Exposición al gas $\mathrm{SO}_{2}$. Comportamiento en un ambiente urbano de carácter ácido. (iii) Exposición a niebla salina y rayos UV. Resistencia de la capa protectora a corrosión salina y radiación solar. Los valores de aceptación propuestos para un producto cualquiera utilizado en protección de pizarras, son los siguientes: (1) Valoración visual $\geq 7$ (2) Ensayos de laboratorio: Ciclo térmico: T1; Exposición $\mathrm{SO}_{2}$ : grado A; Niebla salina + rayos UV: grado 1. Estos valores se pueden ajustar dependiendo de los requisitos que se establezcan inicialmente.

\section{AGRADECIMIENTOS}

El presente trabajo ha sido desarrollado en el Centro Tecnológico de la Pizarra, Sobradelo de Valdeorras y en la

\section{CONCLUSIONS}

The present protocol tries to fill the present vacuum evaluating a protective product for roofing slate. Only in recent years the slate industry is looking for valuable solutions to the alterations that undergo some slates throughout their life on the roof. The development of new products requires valid tools of diagnosis of its effectiveness. The combination of the enclosed technological tests together with the proposed visual questionnaire allows granting a quality index. Each one of the three tests proposed in this protocol uses a property of the slate treatment, as follows: (i) Thermal cycle. Resistance of the protective coating to oxidation of iron sulphides. (ii) Exposition to $\mathrm{SO}_{2}$. Behaviour in urban environment of acid character. (iii) Exhibition to saline fog and rays UV. Resistance of the protective coating to saline corrosion and solar radiation. The proposed values of acceptance for a product used in slate protection, are as follows: (1) Visual valuation $\geq 7$ (2) Tests of laboratory: Thermal cycle: T1; Exhibition to $\mathrm{SO}_{2}$ : grade A; Saline fog + UVirradiation: grade 1 . These values can be corrected depending on the established initial requirements.

\section{ACKNOWNLEDGEMENTS}

Laboratory experiments were conducted in the Centro Tecnológico de la Pizarra, Sobradelo de Valdeorras and 
Universidad de Santiago de Compostela bajo los Proyectos: "Desarrollo de una metodología para la protección de la pizarra para cubiertas frente a la oxidación" financiado por la Dirección Xeral de $I+D$ de la Consellería de Industria de la Xunta de Galicia. Gracias también los proyectos S-0505/MAT/000094 del autor JGGuinea y CGL2004-03564/BTE. Los autores agradecen su colaboración a Miriam Peralta Martínez, Coating Technology Manager del departamento de I+D de la empresa Sika. the Universidad de Santiago de Compostela. Financial support was provided by the project "Development of a new methodology to protect the roofing slate from oxidation" sponsored by Dirección Xeral de $I+D$ de la Consellería de Industria de la Xunta de Galicia. Thanks are also due to projects S-0505/MAT/000094 of author J.G.Guinea and CGL2004-03564/BTE. We are grateful to Miriam Peralta Martinez, Coating Technology Manager of the R\&D Department of SIKA Company for her valuable advice.

\section{BIBLIOGRAFIA / BIBLIOGRAPHY}

(1) Garcia-Guinea, J., Lombardero, M., Roberts, B., Taboada, J., Peto, A.: "Mineralogia y micro-estructura de la pizarra de techar: Comportamiento termoóptico y fisibilidad". Mater. Construcc, Vol. 48 (1998), pp. 37-48.

(2) B., Silva, Prieto, B., Rivas, T., Sanchez-Biezma, M. J., Paz, G., Carballa, IR.: "Rapid biological colonization of a granitic building by lichens". Inter. Biodeter. \& Biodegr., Vol. 4 (1997), pp. 263-26.

(3) Gaylarde, C. C., Morton, L.H.G., : "Deteriogenic biofilms on buildings and their control: a review". Biofouling Vol. 141 (1999), pp. $59-74$.

(4) Warscheid, T. H., Braams, J.: "Biodeterioration of stone: a review". Inter. Biodeter. \& Biodegr., Vol. 46 (2000), pp 343-368.

(5)Urzi, C., Krumbein, W. E., Warscheid, T.: "On the question of biogenic colour changes of mediterranean monuments (coating - crust - microstromatolite - patina - scialbatura - skin - rock varnish)" In: Decrouez, D., Chamay, J., Zezza, F. (Eds.), Proceedings of the 2nd International Symposium on The conservations of the monuments in the Mediterranean Basin, Musee d'Art et d'Histoire Naturelle: Genève (1992) pp. 397-420.

(6) Guillitte, O.: "Bioreceptivity: a new concept for building ecology studies". Sci. Tot. Environ. Vol. 167 (1995), pp. 215-220.

(7) Urrutia, M., Graña-García, J., Rodeja, R., Macias, F.: "Procesos de oxidación de pirita en medios superficiales: potencial acidificante e interés para la recuperación de suelos de mina" Cuad. Lab. Xeol. Laxe, Vol. 11 (1987), pp. 131-145.

(8) Monterroso, C., Macías, F.: "Drainage waters affected by pyrite oxidation in a coal mine in Galicia (NW Spain): Composition and mineral stability". Sci. Tot. Environ. Vol. 216 (1998) pp. 121-132.

(9) Pérez-López, R., Cama, J., Nieto, J. M., Ayora, C., Almodóvar, G. R.: "Procesos de atenuación de la oxidación de sulfuros en residuos mineros de la Faja Pirítica Ibérica". Macla, Vol. 3 (2005), 151-152.

(10) Evangelou, V. P.: "Potential microencapsulation of pyrite by artificial inducement of ferric phosphate coatings", J. Environ. Quality, Vol. 24, No 3 (1995), pp. 535-542.

(11) Evangelou, V. P.: "Pyrite microencapsulation technologies: Principles and potential field application", Ecol. Engin., Vol. 17 (2001), pp. $165-178$.

(12) Zhang, Y. L., Evangelou, V. P.: "Formation of ferric hydroxide - silica coatings on pyrite and its oxidation behaviour". Soil Sci. Vol. 163 no 1 (1998), pp. 53-62.

(13) Georgopoulou, Z. J., Fytas, K., Soto, H., Evangelou, B: "Feasibility and cost of creating an iron - phosphate coating on pyrrhotite to prevent oxidation". Environ. Geol., Vol. 28 (n² 2) (1996), pp. 61-69.

(14) Jiang, C. L., Wang, X. H., Parekh, B. K.: "Effect of sodium oleate on inhibiting pyrite oxidation". Int. J. Miner. Proces., Vol. 48 (2000), pp. 305-318.

(15) Zhang, X., Borda, M. J., Schoonen, M. A. A., Strongin, D. R.: "Pyrite oxidation inhibition by a cross - linked lipid coating". Geochem. Trans., Vol. 4 (n० 2) (2003), pp. 8-11.

(16) Kargbo, D., Atallah, G., Chatterjee, S.: "Inhibition of pyrite oxidation by a phospholipid in the presence of silicate". Environ. Sci. Technol., Vol 38 (2004), pp. 3432-3441.

(17) Lalvani, S. B., Deneve, B.A., Weston, A.: "Passivation of pyrite due to surface treatment". Vol. 69 (1990), pp. 1567-1569.

(18) Lalvani S.B., Shami M.: "Passivation of pyrite oxidation with metal cations". J. Mater. Sci. Vol. 22 (1987), pp. 3503-3507.

(19) Costagliola, P., Cipriani, C., Delfa, C.M.: "Pyrite oxidation: protection using synthetic resins". Eur. J. Miner, Vol. 9, No. 1 (1997), pp. 167-174.

(20) V .P., Evangelou: "Oxidation Prof. Silicate surface coating on iron sulphides" US PTO Patent 5.494 .703 (1996) U.S. Patent.

(21) Morel, F. M., Hering, J.G.: "Principles and Applications of Aquatic Chemistry". Ed. Wiley-Interscience: New York (1993), pp. 588

(22) Bhatti, T. M., Bigham, J. M., Carlson, L., Tuovinen, O. H.: "Mineral Products of Pyrrothite Oxidation by Thiobacillus Ferrooxidans". Appl. Environ. Microbiol. Vol. 59 (no 6) (1993) 1984-1990.

(23) Berner, R.: "Sedimentary pyrite formation: An update". Geochim. Cosmochim. Act. Vol. 48 (1983), pp. 605-615.

(24) Cardenes, V., Lombardero, M., Garcia-Guinea, J., Pais-Diz, V.: "Determinación de sulfuros de hierro en pizarras para cubiertas". Roc Maquina, Vol. 77 (2002), pp. 90-98.

(25) Garcia-Guinea J., Cardenes V., Lombardero M. \& Desiloniz M.I.: Determination of iron sulphides in roofing slates from the north west of Spain. Mater. Construcc. 52 (2002), pp. 55-63.

(26) Cárdenes, V., Pais-Diz, V., García-Guinea, J., Gómez-Fernández, F.: "Pizarras de Techar". En: Seminarios Soc. Esp. Miner., Vol. 2, Utilización de Rocas y Minerales Industriales (2006), pp. 183-217. Ed. SEM. Alicante. 
(27) Sawlowicz, Z.: "Pyrite framboids and their development: a new conceptual mechanism". Geol Rundsch, no 82 (1993), pp. 148-156. (28) UNE-EN 12326-1: (2005). Productos de pizarra y piedra natural para tejados y revestimientos discontinuos. Parte 1: Especificación de producto. Parte 2: Métodos de ensayo.

(29) EN 13501-5: (2005). Clasificación en función del comportamiento frente al fuego de los productos de construcción y elementos para la edificación. Parte 5: Clasificación en función de datos obtenidos en ensayos de cubiertas ante la acción de un fuego exterior.

(30) UNE-EN ISO 11997-(1-2): (2007). Pinturas y barnices. Determinación de la resistencia a condiciones cíclicas de corrosión. Partes (12): Humedad (niebla salina) / sequedad / humedad / luz UV.

(31) UNE-EN 14147: (2004). Métodos de ensayo para la piedra natural. Determinación de la resistencia al envejecimiento por niebla salina. (32) UNE-EN ISO 4628-1: (2004). Pinturas y barnices. Evaluación de la degradación de los recubrimientos. Designación de la intensidad, cantidad y tamaño de los tipos más comunes de defectos. (1): Introducción general y sistema de designación. (2): Evaluación del grado de ampollamiento. (3): Evaluación del grado de oxidación. (4): Evaluación del grado de agrietamiento. (5): Evaluación del grado de descamación. (33) ASTM 4329-84 (1984). Standard Practice for Operating Light-And Water-Exposure Apparatus (Fluorescent UV Condensation Type) for Exposure of Plastics.

(34) ASTM C217-94 (2004) Standard Test Method for Weather Resistance of Slate.

(35) Rasband, W.S., Image, J,: U. S. National Institutes of Health, Bethesda, Maryland, USA, http://rsb.info.nih.gov/ij/, $1997-2006$. 